УДК 73.3.013.42:316.48

DOI 10.11603/2411-1597.2020.4.11871

\title{
ЗМІСТОВІ ТА ОРГАНІЗАЦІЙНІ ОСНОВИ ТЕХНОЛОГІЇ МЕДІАТОРСТВА МЕДИЧНОЇ СЕСТРИ У ВИРІШЕННІ КОНФЛІКТІВ МГЖ ШКОЛЯРАМИ
}

\author{
О. І. Пилипишин, А. Г. Данилюк \\ Тернопільський національний медичний університет \\ імені І. Я. Горбачевського МОЗ Украӥни
}

\begin{abstract}
У статті обгрунтовано соціально-педагогічну технологію медіаторства як технологію вирішення конфліктів між учнями в загальноосвітньому навчальному закладі, охарактеризовано їі специфіку та алгоритм. Сформульовано визначення соціально-педагогічної технології медіаторства у вирішенні конфліктів між школярами: це - комплексна, об’єднуюча єдиною концепцією діяльність різних суб’єктів, спрямована на досягнення однієї мети; стандартний комплекс методично описаних і послідовно впроваджених дій і процедур, результатом яких є налагодження ефективної системи врегулювання конфліктів між підлітками шляхом використання конструктивної комунікації й аналізу конфліктної ситуації на засадах порозуміння та задоволення інтересів і потреб усіх учасників конфлікту.
\end{abstract}

\section{CONTENT AND ORGANIZATIONAL FUNDAMENTALS OF NURSE MEDIATION TECHNOLOGY IN RESOLVING CONFLICTS BETWEEN SCHOOLCHILDREN}

\author{
O. I. Pylypyshyn, A. G. Danilyuk
}

\section{Horbachevsky Ternopil National Medical University}

The article substantiates the socio-pedagogical technology of mediation as a technology for resolving conflicts between students in a secondary school, describes its specifics and algorithm. The definition of socio-pedagogical technology of mediation in resolving conflicts between students is formulated: it is a complex activity uniting a single concept of different subjects, aimed at achieving one goal; a standard set of methodically described and consistently implemented actions and procedures, the result of which is the establishment of an effective system for resolving conflicts between adolescents through the use of constructive communication and analysis of the conflict situation based on understanding and meeting the interests and needs of all parties.

Вступ. На основі аналізу наукових підходів і емпіричного досвіду стану конфліктності між школярами та приймаємо як вихідну тезу, що конфлікти є природними для даного віку й мають конструктивний потенціал для особистісного становлення школяра. Важливо навчитися керувати таким станом і адекватно використовувати потенціал цього вікового періоду. Тому сконцентруємо увагу на формах, які стимулюють продуктивну поведінку особистості в конфліктних ситуаціях, сприяють створенню безпечного середовища, активізують цивілізовану поведінку школяра, орієнтовану на суспільні цінності.

У якості конструктивної технології створення безпечного і толерантного середовища успішної соціалізації школярів розглядаємо медіаторство (медіацію), що трактується як альтернативна технологія урегулю-

(c) О. І. Пилипишин, А. Г. Данилюк, 2020 вання і вирішення спорів, залагодження конфліктів, примирення конфліктуючих сторін на основі організації та проведення переговорів між ними за допомогою незалежного посередника (медіатора) [1].

Медіацію розуміємо як певний підхід до розв'язання конфлікту, в якому нейтральна третя сторона (медіатор) забезпечує структурований процес для того, щоб допомогти конфліктуючим сторонам прийти до взаємно прийнятного вирішення спірних питань. До функцій медіатора належить допомога у прийнятті рішення сторонами, налагодженні діалогу заради примирення, а не винесення рішення замість учасників конфліктної ситуації.

Основна частина. Медіатор (нейтральна сторона) виступає в ролі посередника у вирішенні конфлікту сторонами, сприяє створенню атмосфери конструктивної комунікації та турбується про толерантність 
сторін відносно одна до одної. А також допомагає налагоджувати взаєморозуміння, слідкує за процесом переговорів, спонукає сторони реалістично оцінювати ситуацію, приймати адекватні рішення, сприяє зменшенню емоційного напруження тощо.

Медіаторами, на нашу думку, в умовах загальноосвітньої школи можуть бути психологи, педагоги, соціальні педагоги, медичні сестри, самі учні.

Використовуючи медіацію при вирішенні конфлікту, сторони налаштовуються на метод співробітництва, в чому і полягає основна мета медіатора неупереджено підійти до обговорення ситуації, яка виникла, та сприяти тому, щоб сторони прийняли взаємоприйнятне рішення для ії̈ врегулювання. Варто зазначити, що медіатор не бере участі у прийнятті рішення, а натомість:

- сприяє висловленню кожним учасником конфлікту свого бачення ситуації, власної точки зору;

- контролює, щоб сторони переговорів були почутими одна одною, висловили всі свої побоювання та страхи, які виникають у них;

- резюмує сказане та визначає ключові питання, стосовно яких здійснюють переговори та приймають рішення;

- акцентує увагу на спільних позиціях та інтересах сторін. Важливим у розкритті сутності медіації як альтернативної технології розв'язання конфліктів $\epsilon$ аналіз її принципів. У загальноприйнятому значенні принципи це - вихідні засади, відправні начала, ідеї, дороговкази, загальні вимоги [2]. Система принципів $\epsilon$ наріжним каменем побудови будь-якого механізму розв'язання конфліктів.

Під принципами медіації учені розуміють «вихідні й визначальні ідеї, положення та засади, які становлять процедурне та організаційне підґрунтя здійснення процедури медіації і спрямовані на ефективне, взаємоприйнятне, законне розв'язання конфлікту між учасниками спору» [3].

Одним із найбільш значущих напрямів застосування медіації $є$ інтеграція її в систему освіти і виховання, що позначається узагальнюючим терміном «шкільна медіація». Аргументи цього вектора розкриваються у працях американських дослідників Д. Джонсон [4], Р. Коен [5, 6], українських теоретиків і практиків А. Горової [7], Н. Заверико [8], Р. Коваль та ін.

Шкільні служби медіації (порозуміння, примирення і т. ін.) описуються у працях науковців як інновації в соціально-педагогічній діяльності, наприклад, Н. Суховєєва аналізує сутність і такої служби як інноваційного явища та інтегративної моделі впровадження відновних практик для вирішення конфліктів і профілактики насильства і підліткових правопорушень. Авторка визначає соціально-педагогічні аспекти шкільної медіації і перспективи їі впровадження в умовах української школи [9].

Теоретичні й прикладні аспекти діяльності шкільних служб порозуміння в Україні, особливості й поетапність їх створення всебічно розкриті в колективній праці «Шкільна служба порозуміння: досвід упровадження». Автори А. Горова, Р. Коваль та ін., крім того, що узагальнили й систематизували досвід української практики організації служб медіації у школах, запропонували програму навчального тренінгу для підготовки медіаторів-однолітків серед старшокласників загальноосвітніх шкіл.

Існує на сьогодні певна кількість вітчизняної та зарубіжної літератури, в якій описуються практичні аспекти та поради для створення шкільних служб медіації:

- алгоритм створення служби медіації в школі, практичні рекомендації з організаціїї̈ роботи, поради медіатору-ровеснику презентує посібник «Шкільний центр медіації. Крок за кроком» (упорядники Л. Шестакова, А. Кашина);

- про можливості й методику застосування шкільної медіації як технології розв'язання та попередження дитячих конфліктів в умовах нинішньої української реальності - в період військового конфлікту йдеться в колективному навчально-методичному посібнику «Соціально-педагогічна та психологічна допомога сім'ям з дітьми в період військового конфлікту» [11];

- процедуру створення у навчальному закладі соціальної служби розв'язання конфліктів і роль соціального педагога у цьому процесі описує С. Котловий у статті «Діяльність соціального педагога з медіаторами як посередниками у розв'язанні конфліктів» [12];

- досвід впровадження медіації як технології вирішення конфліктів у школі описано у праці О. Зикова «Профілактика патологічних форм залежної 69 поведінки», де детально аналізують кожен етап впровадження, розглядають моделі служби медіації, методичний супровід медіаторів-ровесників, умови довгострокового функціонування шкільної служби порозуміння [13];

- практичне керівництво зі створення і розвитку служб шкільної медіації в освітніх закладах подає А. Коновалов у методично-інструктивній праці «Шкільна служба примирення і відновлювальна культура взаємовідносин»; 
- матеріали для практичного використання медіації в школі як технології формування позитивної культури спілкування пропонує Г. Гурп у праці «Медіація однолітків. Докладний посібник з розв'язання конфліктів у наших школах». Зокрема авторка пропонує тренінгові вправи для навчання дітей медіативній технології, описує методику ознайомлення батьків і адміністрації школи із технологією медіації [15].

Дослідники переконують, що шкільна медіація відкриває нові підходи та шляхи подолання складних і конфліктних ситуацій між учасниками освітнього процесу, що закладено в сутність самої медіації. Зокрема С. Оборотова акцентує увагу на тому, що в основі шкільної медіації - бачення в конфлікті надії на поліпшення і зміну ситуації, на правильне розуміння проблеми, прийняття сторонами одна одної. У такому разі змінюється ставлення до ситуації: стає можливим погляд на проблему з різних точок зору, творче переосмислення ситуації, здійснення неупередженої оцінки, формулювання висновків та обрання конструктивного шляху для вирішення конфліктної ситуації. Таке творче ставлення до конфлікту, стверджує С. Оборотова, зазвичай допомагає прийняти правильне рішення [16].

Основною відмінністю медіації від інших видів вирішення спорів в умовах системи освіти $є$ її недирективність. Такий гнучкий і демократичний спосіб вирішення спорів, оснований на добровільній участі сторін, створює в той же час цим сторонам умови для контролю не тільки за процесом вироблення рішення, але і за якістю цього рішення, гарантуючи їм повну конфіденційність, забезпечуючи збереження репутації і можливості конструктивної взаємодії в майбутньому. Медіація прагне до консенсусних рішень, максимально відображає інтереси і потреби усіх учасників освітньої діяльності, які беруть участь в суперечці, що створює можливість успішного результату для всіх.

Як доводять дослідники і фахівці шкільної медіації - основною метою впровадження медіації у школі $\epsilon$ підвищення результативності навчально-виховного процесу шляхом сприяння попередження та врегулювання конфліктних ситуацій у шкільному середовищі, зокрема:

- створення безпечного і толерантного середовища, сприятливого для розвитку особистості з активною громадянською позицією, яка вміє приймати рішення і відповідати за свої вчинки;

- виховання культури конструктивної поведінки в конфлікті, основаної на медіативному світогляді, в основі якого - визнання цінності людського життя, унікальності кожної окремої особистості, прийняття, повага права кожного на задоволення власних потреб і захист власних інтересів (але не на шкоду чужим інтересам);

- поліпшення якості життя усіх учасників навчально-виховного процесу (якими є сім'я, вихователі, педагоги, адміністратори освітньо-виховних установ, психологи, соціальні працівники, соціальні педагоги, шкільні інспектори, діти, підлітки, юнацтво) за допомогою медіативного підходу, що ґрунтується на позитивному спілкуванні, повазі, відкритості, доброзичливості, взаємному прийнятті як всередині груп дорослих та дітей, так і між цими групами.

Своє бачення завдань шкільної медіації представив А. Коновалов, який доводить, що одним із основних її завдань $\epsilon$ обмеження адміністративно-карального впливу дорослих на підлітків і реакцій школярів на конфлікт, нерідко силових, заміна їх на примирливі зустрічі (в максимальній кількості випадків).

Визначальним для методу шкільної медіації $\epsilon$ те, що в нього апріорі закладено позитивне ставлення до особистості та визнання за нею права залишатися автентичною [17].

Шкільна медіація спирається на ті ж принципи, що і медіація як альтернативний позасудовий спосіб вирішення спорів: добровільність, відкритість, довіру, повагу, неупередженість, рівноправність всіх сторін.

При вирішенні спору витримується конфіденційність, а основне завдання медіатора полягає в тому, щоб створити умови для діалогу сперечальників, допомогти їм усвідомити власні інтереси і прийти до взаємного рішення. У будь-якому випадку медіатор не спонукає учасників спору до прийняття рішення, а лише допомагає їм у процесі діалогу знайти шляхи до виходу з конфліктної ситуації. Але якщо в звичайному процесі медіації достатнім результатом вважається укладання реально виконуваної, життєздатної угоди або компромісу між сторонами, то в шкільній медіації медіатор завжди прагне до глибшого результату - до досягнення консенсусу. Тобто, мова йде про таке вирішення суперечки, що одночасно дозволяє змінити ставлення учасників не тільки до даного конфлікту, а й сприяє формуванню культури конструктивної поведінки в конфлікті, в ситуаціях напруження взагалі.

Важливо розуміти, що створення сприятливого клімату і безпечного простору, а в результаті - і підвищення якості навчання, неможливі без розуміння простої істини, яку часто ігнорують: спілкування є ви- 
хованням. На цьому наголошує і Ц. Шамлікашвілі: «Від якості спілкування залежить і якість освіти. Саме тому однією з основ методу шкільної медіації $є$ позитивне спілкування» [18]. Практичний досвід підтверджує, що дотримання принципів медіації сприяє задоволенню базових психологічних потреб особистості - провідних механізмів психіки людини, що насамперед забезпечує успішність і ефективність медіації.

Висновки. Шкільна медіація $є$ соціальним інструментом, який дозволяє ефективно попереджати і вирішувати суперечки і конфлікти, створюючи безпечне середовище для всіх учасників навчально-виховного процесу. Учні, особливо підлітки, можуть відчувати почуття прийняття та приналежності до тієї групи до-

\section{СПИСОК ЛІТЕРАТУРИ}

1. Дурняк Л. Шкільна медіація як засіб вирішення конфліктів серед підлітків / Л. Дурняк // Педагогіка і психологія професійної освіти. - 2013. - № 5. - С. 191-200.

2. Словник української мови : в 11 томах [Електронний ресурс]. - 1979. - Т. 10. - 441 с. - Режим доступу : /sum. in.ua/s/umova (дата звернення: 23.04.2016 р.).

3. Притика Ю. Д. Зміст та класифікація принципів медіації / Ю. Д. Притика // Бюлетень Міністерства юстиції України. - 2010. - № 10. - С. 86-92.

4. Джонсон Д. В. Соціальна психологія. Тренінг міжособистісного спілкування / Д. В. Джонсон. - К. : ВД «КиєвоМогилянська академія», 2003. - 288 с.

5. Cohen R. Students resolving conflict: Peer Mediation in Schools / R. Cohen. - [Електронний ресурc]. USA: GoodYearBooks, 2005. - 264 p. URL : http://www. schoolmediation.com/books/resolvingconflict/index.html (дата звернення: 10.10.2016р.).

6. Cohen R. The Schoolmediator's field guide R. Cohen. USA, Massachusetts, 1999. - 256 p.

7. Шкільна служба розв'язання конфліктів: досвідупровадження : посібник / Р. Коваль, А. Горова, А. Нікітчук та ін. - К. : Видавець В. О. Захаренко, 2009. - 168 с.

8. Суховєєва Н. М. Шкільні служби порозуміння як інновація в соціально-педагогічній діяльності / Н. М. Суховєєва // Вісник Чернігівського національного педагогічного університету : збірник наукових праць. Серія: Педагогічні науки. Вип. 96 / Чернігівський національний педагогічний університет імені Т. Г. Шевченка. - 2012. - С. 202-205.

9. Заверико Н. В. Медіація як технологія розв'язання конфліктів серед підлітків: вітчизняний та зарубіжний досвід / Н. В. Заверико // Соціальна педагогіка: теорія та практика. - 2012. - № 2. - С. 28-33.

10. Шкільна служба розв'язання конфліктів: досвід впровадження / упоряд. К. Л. Розумовський. - К. : А.С.К., 2007. - 88 c. рослих і однолітків, члени якої за допомогою медіації сприяють інтегруванню учасників конфлікту в групу в широкому сенсі: в колектив класу, школи, в коло однолітків. Це інноваційний метод, який ґрунтується і водночас реалізує сучасні гуманітарні цінності та досягнення, в першу чергу, завдяки створенню безпечного простору, в якому певною мірою відбувається задоволення базових психологічних потреб, прийняття медіатором учасників спору або конфлікту, набуття ними «власного», проявляється така важлива якість медіатора, як «присутність».

11. Соціально-педагогічна та психологічна допомога сім'ям з дітьми в період військового конфлікту : навчально-методичний посібник / упорядники Н. П. Бочкор, Н. В. Лунченко. - К. : Агентство «Україна», 2015. - 176 с.

12. Котловий С. Діяльність соціального педагога 3 медіаторами як посередниками у розв'язанні конфліктів / С. Котловий // Молодь і ринок. - 2015. - № 1 (120). С. 82-86.

13. Профилактика патологических форм зависимого поведения : в 3-х томах / под общей редакцией О. В. Зыкова. Том II. Реабилитационное пространство: ювенальные технологии (вторичная профилактика). - М. : РБФ НАН, 2010. - 436 с.

14. Кристи Н. Конфликты как собственность [Электронный ресурс] / Нильс Кристи. - Режим доступа : http:// sprc.ru/wp-content/uploads/2012/08/ (дата обращения: 12.11.2012 p.).

15. Гурп Г. Медіація однолітків. Докладний посібник 3 розв'язання конфліктів у наших школах [Електронний ресурс] / Г. Гурп // Матеріали тренінгу, 2002. - Режим доступу : http://www.ahmerov.com/book_1129.html (дата звернення: 18.08.2014 р.).

16. Оборотова С. А. Медиация как современная технология управления конфликтами в образовательной среде / С. А. Оборотова // Ценности и смыслы. - 2015. Вып. 1 (35). - С. 116-126.

17. Коновалов А. Ю. Модели работы с конфликтами на основе восстановительной медиации в системе образования [Электронный ресурс] / А. Ю. Коновалов // Психологическая наука и образование psyedu.ru. - 2014. № 3. - Режим доступа : http://psyedu.ru/journal/2014/3/ Konovalov.phtml (дата обращения: 11.11.2016 р.).

18. Шкільний центр медіації. Крок за кроком / упоряд. Л. Шестакова, А. Кашина. - Кіровоград : ЦентральноУкраїнське видавництво, 2012. - 48 с. 